\title{
Impact Of Capital Structure On Profitability In The Manufacturing And Non-Manufacturing Industries Of Pakistan
}

\author{
${ }^{1}$ Hafeez Ullah, ${ }^{1}$ Aun Abbas, ${ }^{2}$ Nadeem lqbal \\ ${ }^{1}$ Indus International Institute DG Khan \\ ${ }^{2}$ Faculty of Management Sciences, Ghazi University DG Khan \\ E-mail address: drnadeemiqbal1@gmail.com
}

\begin{abstract}
Keywords: Total debt; capital structure; profitability, performance; Return on Equity; Return on investment; Earning Per share and Price to Earnings Ratio, leverage.
\end{abstract}

\begin{abstract}
This study motives to analyze and understand the association between capital structure and profitability and the fastidious to measure their significance in manufacturing and non manufacturing industries of Pakistan. The paper adopts a quantitative data of different manufacturing and non manufacturing organizations in Pakistan. The financial statements were analyzed of manufacturing and non manufacturing organizations of Pakistan for the period of 20082013. The study reveals the fact, profitability and debt in manufacturing and non manufacturing industry is an insignificant relationship and a strong positive link between profitability and debt. The population of the study is a Manufacturing and Non-Manufacturing industry of Pakistan and units of analysis is D.G Cement factory and AGTL from Manufacturing industry and, HBL \& Bank Al-Falah from Non-Manufacturing industry. In this paper descriptive statistics were used to interpret the data. It is proved that manufacturing industry has found a strong negative regression between debts and profit and the non- manufacturing has found a strong positive regression between debt and profit.
\end{abstract}

\section{INTRODUCTION}

Every firm wants to maximize the shareholder wealth for this purpose, it uses two ways one is to reinvest its income into the business and the second was to pay the dividend. The firm pays the outstanding ordinary share to the shareholders on the basis of current price. The purpose of the firm is to get the best intention of capital structure could be completed by decreasing cost of capital. The capital structure is the permutation of the debt and equity in the field of finance, which is used by the Watson and Head (2007). It is difficult to measure the capital structure of the firm. The capital structure of the industry is very critical to various stakeholders to maximize the capital return of the firm which also increase the ability of the firm to operate its competitive ethnicity. So today it is an imperative issue which is facing by the manager So is difficult for the analyst to measure debt $\&$ equity to attain the maximum capital structure of the firm and want to minimize the cost of debt because to achieve the fruitful return for the owner of the business. Financial managers always tried to make exertion for ascertaining particular combinations that will minimize the cost profit and also market value. The Gateman (2003) also played an important role and believed that the value of the firm is maximized when the cost of capital is minimized.) The cost of capital of the firm is minimized by the combination of the debt \& equity and hence maximized the profit by the minimize the capital structure of the firm. But unfortunately the managers of the firms do not have a formula for the optimal capital structure. In the modern theory, Miller and Modigliani (1958) also breaking the path with their contribution under the perfect market supposition. Miller and Modigliani about the capital structure of irrelevance theory were first published in 1958. According to this theory a firm finances, it's all assets i.e. based on debt and equity can have no effect on the value of the firm. The value of the firm depends on the productivity and the quality of the assets in which a firm is invested. The shares of the dissimilar are homogenous and those are therefore perfect substitutes for one firm to another. All the shares are traded under the perfect market condition. Miller and Modigliani also correct their statement in which they said that the tax 
deductibility of debt would prevent arbitrage from making the value of all firms. Since the introduction of the Miller and Modigliani capital structure irrelevance theory existence and determination of an optimal capital structure of the firm which is very imperative issues in corporate finance (Ryun, Vasconcellos \& Kish, 1997). The existing theory of the capital structure to explain a choice of practice or provide the practitioners, line of direction with regard to the optimal mix debt and equity in their finance decisions (CAI \& Gosh, 2003). The capital structure is depending on the two main factors of the company one is leverage and the other is assets. Properly all the firms have to evaluate the capital structure so for the implementation to get the optimal capital structure for decision of the finance otherwise firm will have to face different financial problems, such as bankruptcy and financial torment, etc. it is necessary for those firms which want to maximize the profit and minimize the cost of debt. The behavioral signaling theory was defined by the good progress of agreement with CEO and CFO (Baker and Wager, 2012). On the practical focal point is depending on the risks of future earning so in which, finally making a decision for good performance of the banking industry of Pakistan. The agency size of the firms depends on the effect of the agency's ability in which describes the efficiency and effectiveness of the banking industry. The agency represented in two ways of agencies in which first the small agencies and other is the large agencies. The small agency is considered as a lower ability and to also the lower level of performance in which industries face the failure.

Pakistan financial field have been analyzing insignificant modifications since independence in 1947 in which the major issue which is created between the debt and equity. The firms are not able to pay short term liability while the industry suffers into failure. When these industries are not able to pay the liabilities then they also will not be able to perform well. The manufacturing and non manufacturing industries have invested deeply to generate profit for a running business in Pakistan. So, the main reasons the failure of an industry is the bad economy and also faces financial distress (Kibet, Teeny \& Moto, 2011). As result this will bring into the loss of investors' wealth which they invested.

The minority studies the description of the international comparison of capital structure measures (Raj \& Zingales 1995).

\section{OBJECTIVE STATEMENT}

$>$ Impact of capital structure on the Profitability of manufacturing and servicing industries.

$>$ To creates optimal capital structure.

$>$ To finds high quality and high performance in the industries of Pakistan.

$>$ To obtain optimistic value and growth of equity.

$>$ To get the constructive balance of EPS through the different banking industries of Pakistan.

$>$ To find out how debt affects on the capital structure.

\section{LITERATURE REVIEW}

Many researchers, research on the performance of the firms, in which one is E-Bay (2009), determined the capital structure and performance of the firms. The main purpose of the study was to check the link between the debt and financial performance of the listed companies (Karachi stock exchange during the period 2008-2012). The capital structure assessment has been important for the implications of the value of the industry and its cost of capital (Firer et al, 2008). The result which comes from the decision of the capital structure can lead to an increase cost of capital, by this means the lowering the net present value of many firms. Explanatory variables for this study was used as short term of the total debt to total asset while return on equity (ROE), return on assets (ROA), market to book value) ratio (MBVR), earnings per share (EPS) were used as a proxy of accounting and market measures of the firm performance. The results obtained by using multiple regression analysis and indicate that capital structure is negatively related with EPS and ROA while 
it has significant positive relation with ROE. Miller \& Modigliani Theory of Irrelevance In their influential paper, Modigliani and Miller (1958) showed that the firm value is autonomous of the capital structure it takes on (MM irrelevance theory). Their study revealed that a lot of opportunities for the perfection of the capital market if the value of the industry depends on its capital structure. Further, if the investors can determine the capital structure decisions, then both the investors and firms can lead to borrowing at the same rate of interest. So, the theory is out of reach assumptions, yet it gives the basics theoretical background for further research. Trade-off Theory also gives the ideas of the firm for the selection that how much the financial debt and equity by using the balance of cost and benefits. This theory suggests the value of levered firm and the value of unlevered in which plus the current value of the interest tax shields. TAXES according to the definition of the tax it is revenue which is collected by the Government also attain from different sectors. Bankruptcy Costs The possibility of default on debt increases, and then the level of debt also increase beyond the optimal point. The firm should default on repayment of loans; the control of the firm will be switched from shareholders to the bondholders who will try to retrieve their investment through the process of bankruptcy. Because the possible financial distress due to by the higher level of leverage a dismal faced two types of bankruptcy of costs. They faced direct cost and indirect cost. The direct cost is which includes the expense which the firm bear in the operating process. If the firm is a large in size, these costs constitute only a small percentage of the firm. Therefore, for a small firm, these fixed costs comprise higher percentage and are considered an active variant of the firm. The indirect cost arises because of change in investment policies of the firm foresees possible financial suffering, so the solution of the loss which industry tries to cover through the process of research and development. The ownership tried to manage to avoid from the borrowing in this way to reduce the systematic risk (Nam et al.2003). Whereas the Grossman and Hart (1986) and Anderson et al. (2003), in their survey report on their empirical investigation, the report was the negative results show. Agency theory The idea of the agency cost was propounded by Jensen and Meckling (1976) and their studies based on the Fama and Miller (1972). Jensen and Meckling the bad situation in the industry is the agency cost occurs when a possible conflict arises between the shareholders and the managers. Furthermore, when the shareholders work as agent, the managers taking far away the wealth from the bondholders to the shareholders by getting more debt and also invest in the risky project. The managers get more important role of removing many complications of the capital structure of the industries. By putting the studies of Partum and Ismail (2007) also searched that the high leverage leads to decrease the agency cost and increases the level of performance and efficiency. Barclay and Smith (2010) declared that much of finance education was designed to pass on to finance student rules derived to the actions of successful practitioners. The main purpose of the financial management is to capitalize on the wealth of the shareholders in more industries. Shareholder wealth in turn is defined as the current price of the firm's outstanding ordinary shares of the firms. Large shareholders have a temptation to monitor the management to reduce the agency cost (Shleifer and Vishay, 1986). Saied et al (2013) also make a study about the effect of capital structure of many listed companies which connect to the Karachi Stock Exchange Banks of Pakistan during the period for the year 2008-12.

The value of the firm $=$ Debt + Equity. Manufacturing Industry manufacturing and non manufacturing sector earns profit through sale in which the sale probably tangible (Products) or intangible (Services). There is a favourable relationship between profitability and EPS, thus an unfavourable relationship between debt and profitability. Profitability The owner's of the firm has ability to invest its income for the sale of assets and shares to earn profit called profitability. The formula of profitability ratio is given below

Profitability Ratio $=$ Net Profit/ Net sale. Return on Equity It means the firm common stock shareholders who invest their money to generate the profit. It is measured through following formula Return On Equity $=$ Net Income/ Shareholder equity, 20\% Return On Assets It's represents how firms use its total assets and to the generate income.

ROA $=$ Operating Income /Avg. Total Assets Earnings Per Share When firm buy or sell the stock in the market, then the corporations needs come to know the annual earnings per 
share. EPS $=$ Net Income $/$ No. of Outstanding Shares Debt To Equity Ratios It represents the debt ability on the equity. If the debt increases than the equity then it will show that your firm is more risky. It is computed by the following formula Debt To Equity Ratio = Total Debt $/$ Total Equity Price to Earnings Ratio In which the analyst expresses what is the market value how much you earn from a sale. If the market price is greater the purchase price, then the price earnings ratio will be increased and it is known by the following formula PER= Market Price / Earnings Per Share Leverage It represent's to use the cost of fixed assets an attempt to improve profitability. According to the preface of the leverage in which two types occur. Operating leverage It consists of the fixed operating costs associated with the production of goods and services. Degree of Operating Leverage Ratios $=$ Fixed cost/total cost Financial Leverage It represents to utilize of fixed financial costs of the firms like as interest on the debt. Degree of Financial Leverage Ratios $=\%$ change in EPS $/ \%$ change in EBIT

\section{MODEL}

$\mathrm{TD}=\beta 0+\beta 1 \mathrm{CP}+\beta 2 \mathrm{EPS}+\beta 3 \mathrm{ROE}+\beta 4 \mathrm{ROA}+\beta 4 \mathrm{PP}+\beta 4 \mathrm{PE}+\varepsilon \mathrm{i}$

P: Profitability

TD : TOTAL DEBT (Measure short terms plus long term debt)

$\mathrm{CP} \quad$ : Capital Structure (Total debt + Equity)

ROE : Return on Equity (Total Net Income divided / Total Equity)

ROA : Return on Assets (Measure Net Income divided by Total Assets)

EPS : Earning Per Share (Measures Total Net Income Divided by Outstanding share)

PE :Price to Earnings Ratio (Measures Market price divided by EPS)

Ei : show the error terms

CONCEPTUAL FRAMEWORK Independent Variable

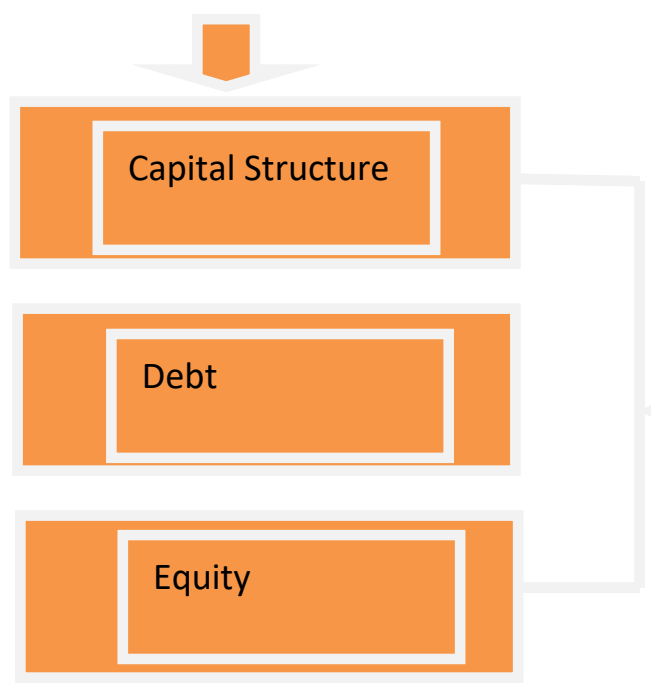

\section{Dependent Variable}

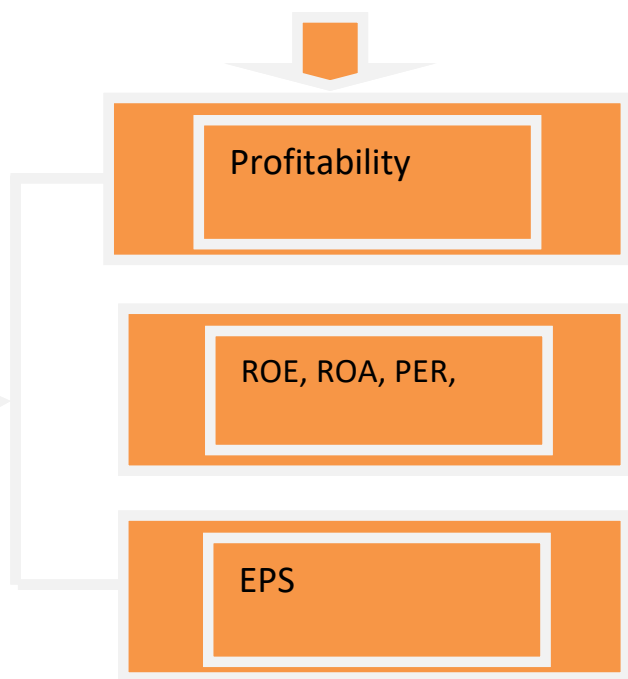

MAUNFACTURING INDUTRIES HYPOTHESIS:

HA1 = Debt shows negative relationship with Profit. HA2 $=$ Debt shows a negative relationship with total EPS. HA3=Debt shows negative relationship with Equity.

NON- MANUFACTURING SECTORS HYPOTHESIS:

HB1= Debt shows a positive relationship with Profit.

HB2=Debt shows a positive relationship with EPS.

HB3=Debt shows a positive relationship with Equity. 


\section{DATA COLLECTION AND METHDOLOGY}

It is not a method of collecting data, but it is a sequence of measure the data which is collected from the following organizations. In which also used the specific variable opts for the predicaments. To find out the corporate governance features of performance this was working in Pakistan. These types of articles also conducted by the many researchers in Pakistan and also by the international pollsters. In which the secondary data techniques were employed. In which also the correlation analysis, regression analysis, descriptive statistic and historical analysis are generally created. This methodology is used for acquiring of the main motives which is analyzing the changes in the debt level to check the performance of the firms. The data for the study is collected from the financial statements of the banks and also with the concerns organizations. In this methodology six year data (2008-2013) were collected from the relevant organizations of both manufacturing and nonmanufacturing which are performing successfully in Pakistan.

In which total debt is taken as the independent variable and the dependent variable is the profitability, ROE, ROA, and also the earning per share.

\section{RESULT AND DISCUSSION}

The figure shows five year Profit two manufacturing sectors (DG. Cement Factory and ALGahzi tractor Factory ) in pakistan. This figure represents variation of profitability. The DG_PRO level is greater variation than AGTL_PRO. It can be seen the profitability amximum of 2013 is approximately 5,500,000 and 100000 . It is proved tha DG cement factory profit level is greater than AGTL_Pro.

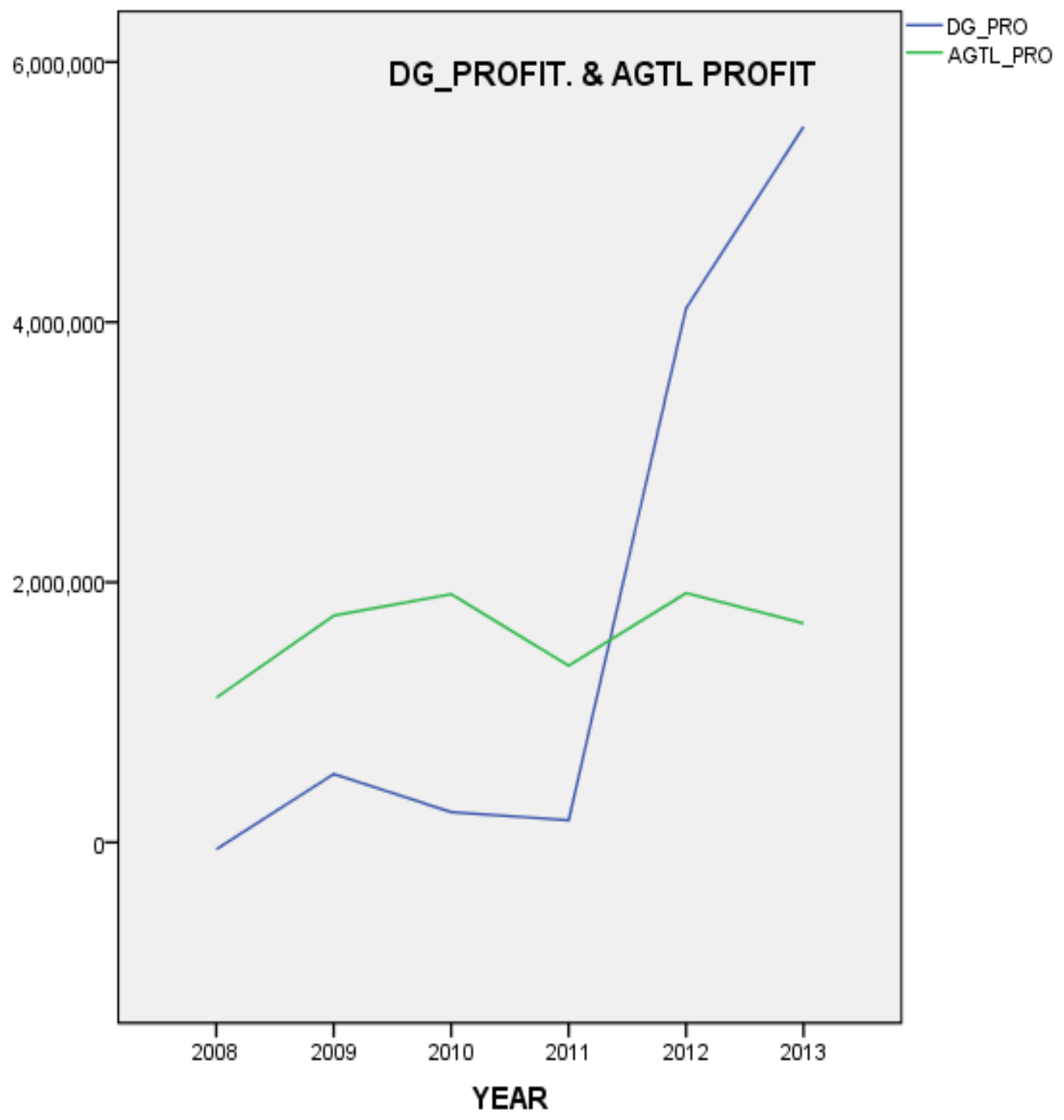




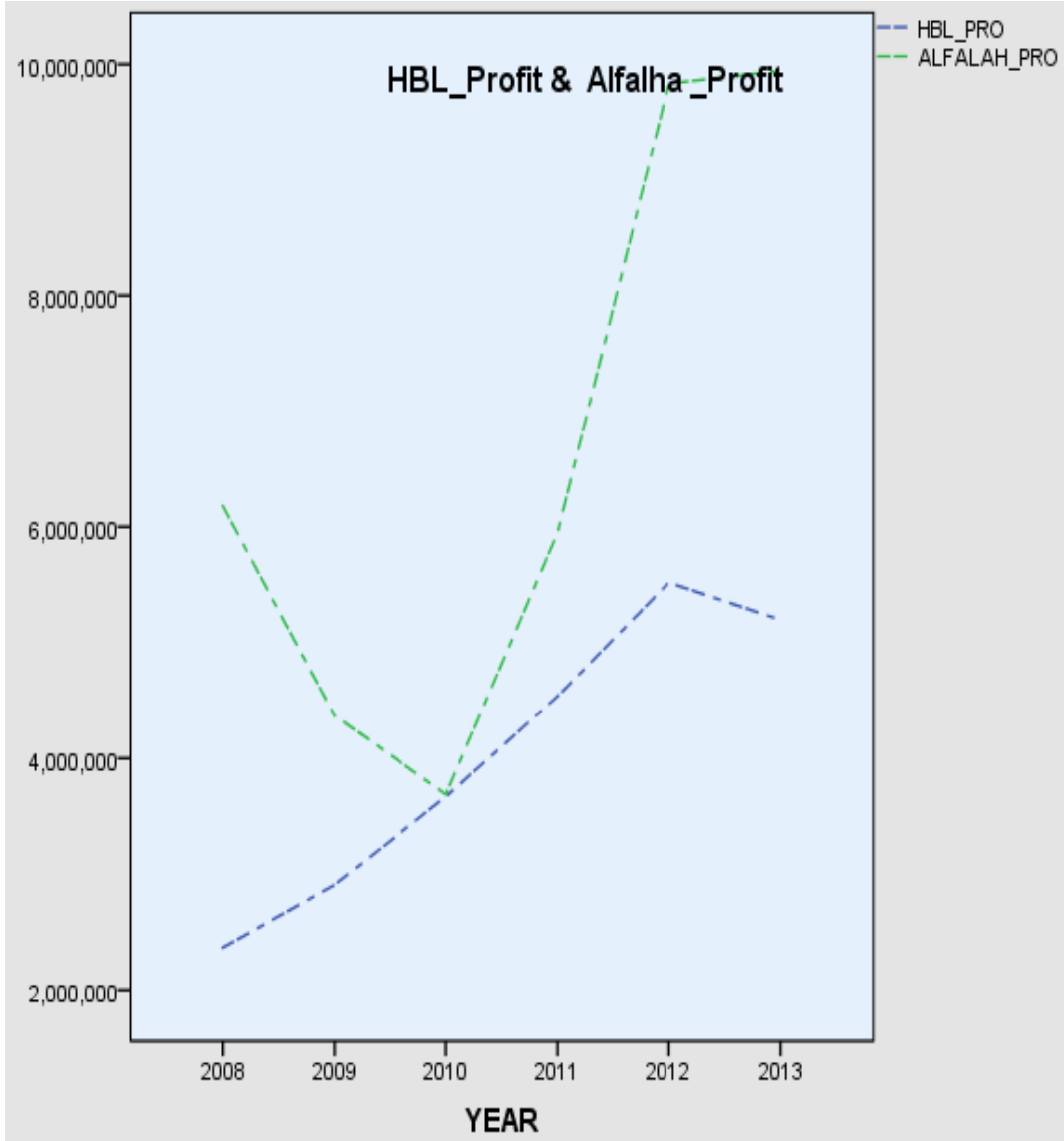

This figure shows that HBL is more profitable than Alfalah

Descriptive Statistics

\begin{tabular}{|c|c|c|c|c|c|c|c|}
\hline & $\mathrm{N}$ & Sum & Std. Deviation & \multicolumn{2}{|c|}{ Skewness } & \multicolumn{2}{|c|}{ Kurtosis } \\
\hline & Statistic & Statistic & Statistic & Statistic & Std. Error & Statistic & $\begin{array}{l}\text { Std. } \\
\text { Error }\end{array}$ \\
\hline DG_EPS & 6 & 25.28 & 5.51139 & 1.007 & .845 & -1.254 & 1.741 \\
\hline DG_PRO & 6 & 10485856.00 & 2416083.71609 & 1.085 & .845 & -1.033 & 1.741 \\
\hline DG_DEBT & 6 & 74876617.00 & 2230339.01951 & .161 & .845 & .357 & 1.741 \\
\hline DG_EQUITY & 6 & 188664048.00 & 9106673.75817 & 1.291 & .845 & 2.704 & 1.741 \\
\hline AGTL_PRO & 6 & 9724906.00 & 321146.74572 & -.877 & .845 & -.600 & 1.741 \\
\hline AGTL_EPS & 6 & 219.29 & 7.77170 & -.202 & .845 & -1.992 & 1.741 \\
\hline AGTL_DEBT & 6 & 21985298.00 & 3244663.44330 & 1.489 & .845 & 1.264 & 1.741 \\
\hline AGTL_EQUITY & 6 & 39121968.00 & 1451699.55047 & -.275 & .845 & -1.068 & 1.741 \\
\hline ALFALAH_PRO & 6 & 39962910.00 & 2671166.92295 & .451 & .845 & -1.801 & 1.741 \\
\hline
\end{tabular}




\begin{tabular}{|c|c|c|c|c|c|c|c|}
\hline ALFALAH_EPS & 6 & 11.79 & 1.33668 & .167 & .845 & -2.824 & 1.741 \\
\hline ALFALAH_DEBT & 6 & 2092905134.00 & 155809428.3435 & -1.607 & .845 & 3.278 & 1.741 \\
\hline ALFALAH_EQUITY & 6 & 324408940.00 & 71822181.83528 & 2.383 & .845 & 5.742 & 1.741 \\
\hline HBL_EPS & 6 & 28.57 & .61917 & -.549 & .845 & -1.438 & 1.741 \\
\hline HBL_PRO & 6 & 24197908.00 & 1264585.06012 & -.164 & .845 & -1.838 & 1.741 \\
\hline HBL_DEBT & 6 & 1915957903.00 & 108955853.6513 & -.295 & .845 & -1.582 & 1.741 \\
\hline HBL_EQUITY & 6 & 100123148.00 & 5223343.58148 & .080 & .845 & -1.580 & 1.741 \\
\hline Valid N (listwise) & 6 & & & & & & \\
\hline
\end{tabular}

\section{MANUFACTURING INDUSTRIES REGRESSION MODEL SUMMARY}

\begin{tabular}{|l|r|r|r|r|}
\hline Model & \multicolumn{1}{|c|}{ R } & R Square & $\begin{array}{c}\text { Adjusted R } \\
\text { Square }\end{array}$ & \multicolumn{1}{c|}{ Std. Error of the Estimate } \\
\hline 1 & $.763^{\mathrm{a}}$ & .582 & .478 & 1746113.37825 \\
\hline
\end{tabular}

The result of the correlation coefficient of the dependent and independent variables are 0.763 , it shows a strong connection by using the rule of thumb, it is a criteria if the result match these rule than the result which are taken by the table also correct 0.0 and 0.20 is very pathetic 0.20 to 0.40 is weak; 0.40 to 0.60 is fair; 0.60 to 0.80 is well-built; and greater than 0.80 is very strong.

Coefficients DG PRO

\begin{tabular}{|rr|r|r|r|r|r|}
\hline \multirow{2}{*}{ Model } & \multicolumn{2}{|c|}{ Un standardized Coefficients } & \multicolumn{1}{c|}{$\begin{array}{c}\text { Standardized } \\
\text { Coefficients }\end{array}$} & \multirow{2}{*}{ T Sig. } \\
\cline { 3 - 5 } & \multicolumn{1}{|c|}{ B } & \multicolumn{1}{c|}{ Std. Error } & \multicolumn{1}{c|}{ Beta } & \\
\hline \multirow{2}{*}{1} & (Constant) & 12062350.211 & 4427064.953 & & 2.725 & .053 \\
& DG_DEBT & -.827 & .350 & -.763 & -2.361 & .078 \\
\hline
\end{tabular}

Dependent Variable: DG_PRO and Independent variable: Total Debt.

To interpret the direction of the relationship between the variables, we look at the coefficient for the independent variable and dependent variable. This hypothesis shows which the effect there is negative relationship between the profit and Debt on the behalf of beta $=-.763$ and the significant is also rejected because the value of $\mathrm{P}$ is more than 0.05 
DG_DEBT $=$ B0 - $\beta 1$ DG_PRO

Hypothesis HA1 $=$ is rejected.

DG EQUITY Coefficients

\begin{tabular}{|rl|r|r|r|r|r|}
\hline \multirow{2}{*}{ Model } & \multicolumn{2}{|c|}{$\begin{array}{c}\text { Un standardized } \\
\text { Coefficients }\end{array}$} & $\begin{array}{c}\text { Standardized } \\
\text { Coefficients }\end{array}$ & \multirow{2}{*}{ T } & \multirow{2}{*}{ Sig. } \\
\cline { 3 - 6 } & \multicolumn{1}{|c|}{ B } & Std. Error & \multicolumn{1}{c|}{ Beta } & \\
\hline \multirow{2}{*}{1} & (Constant) & -5105642.843 & 2460155.218 & & -2.075 & .107 \\
& DG_EQUITY & .218 & .076 & .822 & 2.881 & .045 \\
\hline
\end{tabular}

a. Dependent Variable: DG_PRO

This hypothesis shows that the results in which there is a positive significance between the profit and equity on thebehalf of beta $=.822$ and the significance is as well as accepted. Because the $\mathrm{P}$ value is less than 0.05 .

\section{DG_EQUITY $=\beta 0+\beta 1$ DG_PRO \\ Hypothesis $\mathrm{HA2}$ is= accepted}

DG EPS Coefficients

\begin{tabular}{|c|c|c|c|c|c|c|}
\hline \multirow{2}{*}{\multicolumn{2}{|c|}{ Model }} & \multicolumn{2}{|c|}{$\begin{array}{c}\text { Un standardized } \\
\text { Coefficients }\end{array}$} & $\begin{array}{l}\text { Standardized } \\
\text { Coefficients }\end{array}$ & \multirow[t]{2}{*}{$\mathrm{T}$} & \multirow[t]{2}{*}{ Sig. } \\
\hline & & B & Std. Error & Beta & & \\
\hline \multirow{2}{*}{1} & (Constant) & 26.611 & 10.739 & & 2.478 & .068 \\
\hline & DG_DEBT & $-1.795 \mathrm{E}-006$ & .000 & -.726 & -2.113 & .102 \\
\hline
\end{tabular}

a. Dependent Variable: DG_EPS and Independent variable is debt.

This hypothesis shows that the results in which there is a negative significance between the profit and equity on the behalf of beta $=.726$ and the significance is accepted because the $\mathrm{P}$ value is less than 0.05 .

DG_DEBT $=\beta 0$ - $\beta 2$ DG_EPS

Hypothesis HA3 $=$ is accepted.

It is proved that DG_EPS has negative significance with DG_DEBT.

DG DEBT Coefficients

\begin{tabular}{|c|c|c|c|c|c|c|}
\hline \multirow{2}{*}{\multicolumn{2}{|c|}{ Model }} & \multicolumn{2}{|c|}{ Un standardized Coefficients } & \multirow{2}{*}{$\begin{array}{c}\text { Standardized } \\
\text { Coefficients }\end{array}$} & \multirow[t]{2}{*}{$\mathrm{T}$} & \multirow[t]{2}{*}{ Sig. } \\
\hline & & $\mathrm{B}$ & Std. Error & & & \\
\hline \multirow{2}{*}{1} & (Constant) & 79525744.395 & 8545419.636 & & 9.306 & .001 \\
\hline & DG DEBT & -3.853 & .676 & -.944 & -5.701 & .005 \\
\hline
\end{tabular}

a. Dependent Variable: DG_EQUITY

This hypothesis shows that the results in which there is a negative significance between the profit and equity on the behalf of beta =.-.944 and the significance is accepted because the $\mathrm{P}$ value is less than 0.05 . 


\section{DG_DEBT $=\beta 0-\beta 1$ DG_EQUITY}

Hypothesis $\mathrm{HA3}=$ is accept

It is proved that DG_EQUITY has negative relationship with DG_DEBT.

AGTL Model Summary

\begin{tabular}{|l|l|r|r|r|}
\hline Model & \multicolumn{1}{|c|}{$\mathrm{R}$} & R Square & Adjusted R Square & \multicolumn{1}{c|}{ Std. Error of the Estimate } \\
\hline 1 & $.206^{\mathrm{a}}$ & .043 & -.197 & 1588179.91873 \\
\hline
\end{tabular}

a. Predictors: (Constant), AGTL_DEBT

The relationship between dependent and independent variable is very weak because $\mathrm{R}$ value is less than $50 \%$.

AGTL_PRO Coefficients

\begin{tabular}{|c|c|c|c|c|c|}
\hline \multirow[t]{2}{*}{ Model } & \multicolumn{2}{|c|}{ Un standardized Coefficients } & \multirow{2}{*}{\begin{tabular}{|c|} 
Standardized Coefficients \\
Beta \\
\end{tabular}} & \multirow[t]{2}{*}{$\mathrm{t}$} & \multirow[t]{2}{*}{ Sig. } \\
\hline & $\mathrm{B}$ & Std. Error & & & \\
\hline (Constant) & 1731055.596 & 222139.875 & & 7.793 & .001 \\
\hline AGTL_DEBT & -.030 & .047 & -.304 & -.638 & .558 \\
\hline
\end{tabular}

a. Dependent Variable: AGTL_PRO

This hypothesis shows that the results in that there is a negative significance between the profit and equity on the behalf of beta -.304 and the significance is rejected because $\mathrm{P}$ value is greater than 0.05 .

AGTL_DEBT $=\beta 0-\beta 1$ AGTL_PRO

Hypothesis HA1 $=$ is rejected

: AGTL_EPS Coefficients ${ }^{a}$

\begin{tabular}{|c|c|c|c|c|c|}
\hline \multirow[t]{2}{*}{ Model } & \multicolumn{2}{|c|}{$\begin{array}{c}\text { Unstandardized } \\
\text { Coefficients } \\
\end{array}$} & $\begin{array}{l}\text { Standardized } \\
\text { Coefficients }\end{array}$ & \multirow[t]{2}{*}{$\mathrm{t}$} & \multirow[t]{2}{*}{ Sig. } \\
\hline & $\mathrm{B}$ & Std. Error & Beta & & \\
\hline (Constant) & 42.017 & 4.413 & & 9.521 & .001 \\
\hline AGTL_DEBT & $-1.493 \mathrm{E}-006$ & .000 & -.623 & -1.593 & .186 \\
\hline
\end{tabular}

a. Dependent Variable: AGTL_EPS

This hypothesis shows that the results in which there is a negative significance between the profit and equity on the behalf of beta $=-.623$ and the significance is accepted because the $\mathrm{P}$ value is less than 0.05 .

AGTL_DEBT $=\beta 0-\beta 1$ AGTL_EPS

Hypothesis HA2 $=$ is accepted

It is proved that AGTL_EPS has negative significance with AGTL_DEBT.

Coefficients

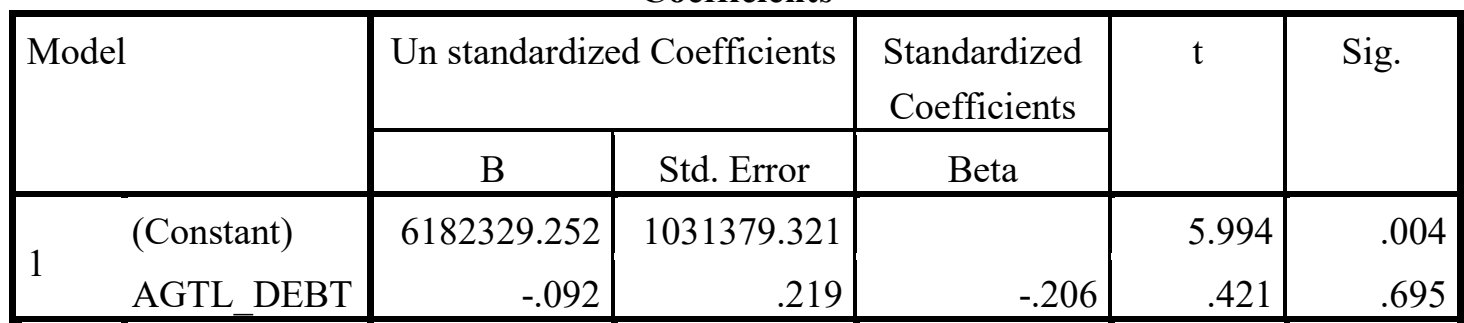

a. Dependent Variable: AGTL_EQUITY

This hypothesis shows that the results in which there is a negative significance between the profit and equity on the behalf of beta $=.695$ the significance is accepted because the $P$ value is less than 0.05 . 


\section{AGTL_DEBT $=\beta 0$ - $\beta 1$ AGTL_EQUITY}

HypothesisHA3 $=$ is accepted.

It is proved that AGTL_EQUITY has negative significance with AGTL_DEBT.

NON̄- MANUFACTURING SECTORS Model Summary

\begin{tabular}{|l|r|r|r|c|}
\hline $\begin{array}{l}\text { Mode } \\
1\end{array}$ & \multicolumn{1}{|c|}{$\mathrm{R}$} & R Square & $\begin{array}{c}\text { Adjusted R } \\
\text { Square }\end{array}$ & $\begin{array}{c}\text { Std. Error of the } \\
\text { Estimate }\end{array}$ \\
\hline 1 & $.993^{\mathrm{a}}$ & .986 & .982 & 170109.13338 \\
\hline
\end{tabular}

The relation between dependent and independent variable is very strong in which $\mathrm{R}$ value is $93 \%$ so this model is much supported.

ALFALAH_PRO Coefficients ${ }^{\mathrm{a}}$

\begin{tabular}{|c|c|c|c|c|c|}
\hline \multirow[t]{2}{*}{ Model } & \multicolumn{2}{|c|}{ Un standardized Coefficients } & \multirow{2}{*}{$\begin{array}{c}\text { Standardized } \\
\text { Coefficients } \\
\text { Beta }\end{array}$} & \multirow[t]{2}{*}{$\mathrm{t}$} & \multirow[t]{2}{*}{ Sig. } \\
\hline & B & Std. Error & & & \\
\hline \multirow{2}{*}{$\begin{array}{ll}1 & \text { (Constant) } \\
& \text { ALFALAH_DEBT }\end{array}$} & 8618342.176 & 3051086.840 & & 2.825 & .048 \\
\hline & 0.08 & .004 & .787 & 14.93 & .026 \\
\hline
\end{tabular}

a. Dependent Variable: ALFALAH_PRO

This hypothesis shows that the results in which there is a positive significance between the profit and equity on the behalf of beta $=.787$ the significance is accepted because the $\mathrm{P}$ value is less than 0.05 .

\section{ALFALAH_DEBT $=\beta 0+\beta 1$ ALFALAH_PRO}

HB1 $=$ is accepted.

It is proved that ALFALAH_PRO has positive relationships with ALFALAH_DEB

HBL_PRO Coefficients

\begin{tabular}{|rl|r|r|r|r|r|}
\hline \multirow{2}{*}{ Model } & \multicolumn{2}{|c|}{ Un standardized Coefficients } & Standardized Coefficients & \multirow{2}{*}{ T } & \multirow{2}{*}{ Sig. } \\
\cline { 3 - 6 } & \multicolumn{1}{|c|}{$\mathrm{B}$} & Std. Error & Beta & & \\
\hline \multirow{2}{*}{1} & (Constant) & 353679.677 & 233525.101 & & 1.515 & .204 \\
& HBL_DEBT & .012 & .001 & .993 & 16.502 & .000 \\
\hline
\end{tabular}

a. Dependent Variable: HBL_PRO

This hypothesis shows that the results in which there is a positive significance between the profit and equity on the behalf of beta $=.993$ the significance is accepted because the $\mathrm{P}$ value is less than 0.05 .

\section{HBL_DEBT $=\beta 0+\beta 1$ HBL_PRO}

Hypothesis $\mathbf{H B 1}=$ is accepted.

It is proved that HBL_PRO has positive relationship between HBL_DEBT

\section{: HBL EPS Coefficients}

\begin{tabular}{|r|r|r|r|r|r|}
\hline \multirow{2}{*}{ Model } & \multicolumn{2}{|c|}{$\begin{array}{c}\text { Un standardized } \\
\text { Coefficients }\end{array}$} & $\begin{array}{c}\text { Standardized } \\
\text { Coefficients }\end{array}$ & \multirow{2}{*}{ T } & \multirow{2}{*}{ Sig. } \\
\cline { 2 - 5 } & \multicolumn{1}{|c|}{ B } & Std. Error & Beta & & \\
\hline \multirow{2}{*}{\begin{tabular}{l} 
(Constant) \\
\cline { 2 - 6 }
\end{tabular}} & 3.179 & .465 & & 6.841 & .002 \\
HBL_DEBT & $4.957 \mathrm{E}-009$ & .000 & .872 & 3.568 & .023 \\
\hline
\end{tabular}

a. Dependent Variable: HBL_EPS

This hypothesis shows that the results in which there is a positive significance between the HBL_EPS and HBL_DEBT on the behalf of beta $=.872$ the significance is accepted because the $P$ value is less than 0.05 . HBL_DEBT $=\beta 0+\beta 1$ HBL_EPS 
Hypothesis $\mathbf{H B 2}=$ is accepted.

It is proved that HBL_EPS has positive relationship between HBL_DEBT.

HBL_EQUITY Coefficients ${ }^{\mathrm{a}}$

\begin{tabular}{|c|c|c|c|c|c|c|}
\hline \multirow[t]{2}{*}{ Model } & & \multicolumn{2}{|c|}{$\begin{array}{c}\text { Un standardized } \\
\text { Coefficients }\end{array}$} & \multirow{2}{*}{$\begin{array}{c}\text { Standardized } \\
\text { Coefficients } \\
\text { Beta }\end{array}$} & \multirow[t]{2}{*}{$\mathrm{t}$} & \multirow[t]{2}{*}{ Sig. } \\
\hline & & $\mathrm{B}$ & Std. Error & & & \\
\hline \multirow{2}{*}{1} & (Constant) & 1557872.518 & 1223021.400 & & 1.274 & .272 \\
\hline & HBL DEBT & .047 & .004 & .988 & 12.957 & .000 \\
\hline
\end{tabular}

a. Dependent Variable: HBL_EQUITY.

This hypothesis shows that the results in which there is a positive significance between the HBL_EQUITY and HBL_DEBT y on the behalf of beta $=.988$ the significance is accepted because the $\mathrm{P}$ value is less than 0.05 .

\section{HBL_DEBT $=\beta 0+\beta 1$ HBL_EQUITY.}

Hypothesis $\mathrm{HB} 3=$ is accepted

It is proved that HBL_EQUITY has positive relationship with HBL_DEBT.

\section{DISCUSSION AND CONCLUSION}

This paper has checked the impact of change in capital structure on the profitability. The ruling specifies that capital structure of sample of manufacturing and non manufacturing industries change with the change of capital structure it effect the profitability significance or insignificance. So it is proved that most of the manufacturing industries have been found that negative impact between profitability and total debt while servicing sectors have positive impact with profitability and debt. It shows discrepancy of capital structure over five years. The major statement of objective to maintains on the profitability in both industries. So, if overcome of such problems such as loss, risk, liabilities and other factors that affect the profitability.

\section{References}

[1] Abort, J. (2005). The effect of capital structure on profitability: An empirical analysis of listed firms in Ghana. The Journal of Risk Finance, 6(5), 438-445.

[2] Abort, J. (2007). Corporate governance and financing decisions of Ghanaian listed firms. Corporate Governance, 7, 83-92.

[3] Akintoye, I. R. (2008).Sensitivity of Performance to Capital Structure. European journal a social sciences $7(1)$.

[4] Baker, M. \& Wurgler, R. (2002).Market Timing and Capital Structure. Journal of Finance 57, 1-32.

[5] EBay, E. I.(2009). The impact of capital-structure choice on firm performance: empirical evidence from Egypt. The Journal of Risk Finance, 10(5), 477-487.

[6] Frank, M. Z., \& Royal, V. K. (2003, April 17). Capital Structure Decisions.

[7] Gitman, L.J. (1997). Principles of Managerial Finance.(Seventh Edition). New York: Harper Collins College Publishers, pp. 684-710.

[8] Grossman, S., \& Hart, O. (1986), the costs and benefit of ownership: A theory of vertical and lateral integration. Journal of Political Economy, 94, 691-719.

[9] Jensen, M. (1986). Agency cost of free cash flow corporate finance and takeovers. American Economic Review Papers and Proceedings, 76, pp. 323-329. 
[10] Kaplan, S. 1989.The effects of management buyouts on operating performance and value. Journal of Financial Economics, 24, pp. 217- 254.

[11] Miller, M.H. (1977), —Debt and Taxes\|, Journal of Finance, Vol. 32.

[12] Modigliani, F. and Miller, M. (1958) „The Cost of Capital, Corporation Finance and Theory of Investmente, the American Economic Review, 48(3), pp. 261-297 [Online] Available at: http://www.jstor.org/stable/1809766 (Accessed 1/6/2010).

[13] Modigliani, F. and Miller, M. (1963) „Corporate income taxes and the cost of capital: a correction"e, The American Economic Review, 53(3), pp. 433-443 [Online] Available at: http://www.jstor.org/stable/1809167 (Accessed 1/6/2010

[14] Modigliani, F., \& Miller, M. (1963). Corporate income taxes and the cost of capital: A correction. American Economic Review, 53, 443-53.

[15] O.C. and O. Anthony, 2012. Impact of profitability in accepted companies of Tehran stock capital structure on the financial performance of exchange. Journal of Basic and Applied Scientific Nigerian firms Arabian Journal of Business and Research. 